\title{
PENGEMBANGAN BUKU AJAR TEORI TENIS MEJA BAGI MAHASISWA KELAS A 2016 JURUSAN PJKR IKIP BUDI UTOMO MALANG
}

\author{
Irwansyah $^{1)}$ \\ Pendidikan Jasmani Kesehatan dan Rekreasi \\ Fakultas Pendidikan Ilmu Eksakta dan Keolahragaan IKIP Budi Utomo \\ Email: 1irwansyahhf@gmail.com
}

\begin{abstract}
ABSTRAK
Pembelajaran yang baik adalah pembelajaran yang mampu menciptakan situasi belajar aktif sepanjang masa. Tujuan dari penelitian ini adalah untuk mengembangkan buku ajar tenis bagi mahasiswa jurusan pendidikan jasmani kesehatan dan rekreasi. Penelitian ini merupakan penelitin pengembangan, yang dilakukan di IKIP Budi Utomo Malang. hasil dari penelitian pengembangan buku ajar tenis meja bagi mahasiswa jurusan pendidikan jasmani kesehatan dan rekreasi (PJKR) IKIP Budi Utomo Malang, ini sudah sempurna dengan "kategori baik", sehingga buku ajar tenis meja tersebut telah dapat digunakan sebagai media untuk meningkatkan kualitas pembelajaran sehingga mahasiswa memiliki bekal keilmuan yang berkompeten, selain itu keberadaan buku ajar dapat dijadikan bahan kajian dan sumber belajar tenaga pendidik.
\end{abstract}

Kata kunci: Pengembangan, Buku Ajar, Matakuliah Tenis Meja

\section{ABSTRACT}

Good learning is learning that is able to create an active learning situation throughout the ages. The purpose of this research is to develop textbook of tennis for students majoring in physical education of health and recreation. This research is a development research, conducted in IKIP Budi Utomo Malang. the result of the research of the development of textbooks for the students of health and recreation (IKIP) Budi Utomo Malang, has been perfect with the "good category", so that the table tennis textbook can be used as a medium to improve the quality of learning so that students has a provision of competent scholarship, in addition to the existence of textbooks can be used as study materials and learning resources of educators.

Keywords: Development, Textbook, Table Tennis Course

\section{Pendahuluan}

Manusia membutuhkan pendidikan dalam kehidupannya, pendidikan merupakan usaha agar manusia dapat mengembangkan potensi dirinya melaluiproses pembelajaran dan/atau cara lain yang dikenal dan diakui oleh masyarakat. Kebutuhan akan pendidikan yang baik, yang mampu meningkatkan kualitas bangsa, mengembangkan karakter, memberikan keunggulan dan kemampuan berkreasi, semakin

\footnotetext{
Irwansyah, Pengembangan Buku Ajar Teori Tenis Meja Bagi Mahasiswa Kelas A 2016 Jurusan Pjkr Ikip Budi Utomo Malang

$P$ a g e | 47
} 
dirasakan urgensinya. Otonomi di bidang pendidikan memberikan kesempatan dan wewenang untuk melakukan inovasi dalam pengembangan dan implementasi kurikulum, pembelajaran, bimbingan dan manajemen pendidikan

Pendidikan itu sendiri dibagi dalam dua jenjang pendidikan yaitu pendidikan formal, pendidikan non formal, dan pendidikan informal. Pendidikan formal adalah jalur pendidikan yang terstruktur dan berjenjang yang terdiri atas pendidikan dasar, pendidikan menengah dan pendidikan tinggi. Pendidikan tinggi adalah jenjang pendidikan pada jalur pendidikan formal setelah pendidikan menengah yang dapat berupa program pendidikan diploma, sarjana, megister, spesialis, dan doktor yang diselengarakan oleh perguruan tinggi (UU R.I NO.20 Tahun 2003 Pasal I), jadi Perguruan tinggi merupakan salah satu lembaga pendidikan yang melahirkan calon guru, yang nantinya akan mengabdi di lembaga pendidikan mulai dari tingkat sekolah dasar (SD/MI) hingga sekolah menengah atas (SMA/MA/SMK) yang memiliki kemampuan di bidang akademik dan profesi yang handal. Perguruan tinggi merupakan wadah untuk membekali, mengarahkan, mengembangkan bakat, dan minat bagi mahasiswa sebagai modal untuk menjadi seorang guru yang profesional.

IKIP Budi Utomo Merupakan salah satu lembaga pendidikan tinggi yang melahirkan tenaga pendidik, dalam proses pembelajaran masih banyak meningalakn permasalahan. Kenyataan di lapangan menunjukkan bahwa proses pembelajaran yang terjadi, khususnya pada matakuliah tenis meja di peguruan tinggi IKIP Budi Utomo Malang, masih banyak dilakukan dengan cara penyajian verbal, di mana dosen mengajar di ruangan dengan menyampaikan sejumlah materi untuk di pelajari oleh mahasiswa. hal ini dilakukan dikarenakan sumber bacaan yang ada untuk matakuliah tenis meja masih sangat minim. Matakuliah tenis meja (MKK 018) ini terdiri dari dua kegiatan yaitu satu kegiatan secara teori dan dua kegiatan secara praktek dilapangan. Kegiatan secara teori mempunyai tujuan mahasiswa dapat menjelaskan berbagai hal yang berkaitan dengan tenis meja, dan secara praktek mahasiswa mampu menjelaskan dan menguasai teknik dasar permainan tenis meja.

Permainan tenis meja adalah suatu permainan dengan menggunakan fasilitas meja dan perlengkapannya serta raket dan bola sebagai alatnya (Larry Hodges, 2007:25). Menurut (Midgley, 2000:146) "Tenis meja adalah merupakan suatu pertandingan antara dua orang pemain "single" atau empat orang "double" menggunakan 
bet sebagai pemukul untuk memukul bola kecil yang ringan ke belakang dan ke depan sepanjang meja yang dibatasi oleh net".

Dari beberapa pendapat yang dikemukakan oleh para ahli maka dapat di simpulkan bahwa tenis meja adalah salah satu cabang olahraga yang dimainkan oleh dua orang (untuk tungal) atau dua pasang (untuk ganda) yang menggunakan bola kecil yang terbuat dari celluloid dan bet sebagai alat pemukul yang dimainkan di atas meja yang di batasi oleh net.

Beberapa jenis pukulan yang biasa dilakukan untuk memukul atau mengembalikan pukulan dari lawan dalam permainan tenis meja, adapun unsur-unsur pukulan dasar dalam tenis meja meliputi:

1. Pukulan Forhand

Adalah setiap pukulan yang dilakukan dengan bet yang digerakkan ke arah kanan siku untuk pemain yang menggunakan tangan kanan, dan ke kiri untuk pemain yang menggunakan tangan kiri, (Hodgs, 2007:XII). Pukulan forehand, pada waktu memukul bola, posisi telapak tangan yang memegang bet/raket menghadap ke depan, (Sutarman, 2008:21). Pukulan forehand digunakan untuk memukul bola yang mengarah ke tangan yang memegang bet setelah memantul ke maja, (Widyarso, 2008:82). Berdasarkan dari beberapa pendapat di atas yang dimaksud dengan pukulan forehand adalah pukulan yang dilakukan di sebelah kanan bagi pemain yang menggunakan tangan kanan atau pukulan yang dilakukan di sebelah kiri bagi pemain yang menggunakan tangan kiri (kidal).

\section{Pukulan Backhand}

Pukulan backhand, pada waktu memukul bola, posisi telapak tangan yang memegang bet/raket menghadap ke belakang, atau posisi punggung tangan yang memegang bet/raket, (Sutarman, 2008:21).

Pukulan backhand adalah digunakan untuk memukul bola yang mengarah ke sisi tubuh yang tidak memegang bet/raket setelah memantul ke maja, (Widyarso, 2008:85).

Berdasarkan dari beberapa pendapat di atas yang dimaksud dengan pukulan backhand adalah pukulan yang dilakukan di sebelah kiri bagi pemain yang menggunakan tangan kanan atau pukulan yang dilakukan di sebelah kanan bagi pemain yang menggunakan tangan kiri (kidal). 


\section{Servis}

Servis adalah pukulan pertama, yang dilakukan oleh server, (Hodges, 2007:XIV). Servis adalah memukul bola pertama kalinya dalam suatu rally, (PTMSI, 2008:3). Servis adalah pukulan yang paling penting dalam tenis meja karena digunakan untuk mengawali setiap point, (Widyarso, 2008:79). Berdasarkan dari beberapa pendapat di atas yang dimaksud dengan pukulan servis adalah setiap pukulan untuk mengawali atau menyajikan bola pertama pada suatu permainan.

\section{Lob}

Lob adalah pukulan dimana bet bergerak ke atas di bawah bola dan memukulnya tinggi ke udara, (Lardner, 1996:71). Lob adalah pukulan melengkung tinggi dengan dasar yang tidak jauh beda dengan pukulan forehand maupun backhand, (Brown, 1996: 87). Berdasarkan dari beberapa pendapat di atas yang dimaksud dengan pukulan lob adalah pukulan yang dilakukan di bawah bola untuk dilambungkan tinggi

\section{Pukulan Push}

Pukulan Push adalah pukulan backspin pasif yang dilakukan untuk menghadapi backspin, (Hodges, 2007:64). Push adalah teknik memukul bola dengan gerakan mendorong dan sikap bet terbuka, (Muhajir, 2008:30).

\section{Pukulan Block}

Block adalah pukulan dengan mengembalikan bola yang cepat, segera setelah memantul dengan pukulan yang agresif, (Hodges, 2007:X). Block adalah teknik memukul bola dengan gerakan menghentikan bola atau membendung bola dngan sikap bet tertutup, (Muhajir, 2008:31).

\section{Pukulan Chop}

Chop adalah teknik memukul bola dengan gerakan seperti menebang pohon dengan kapak atau disebut juga membacok, (Muhajir, 2008:31). Chop adalah pengembalian pukulan yang bersifat bertahan dengan menggunakan backspin, (Hodges, 2007:XI). 


\section{Pukulan Smash}

Smash adalah bola dipukul dengan kecepatan yang cukup sehingga lawan tidak dapat mengembalikannya, (Hodge, 2007:XIV).

Undang-Undang sisdiknas RI Nomor 20 Tahun 2003 Bab II pasal 3 pendidikan nasional berfungsi mengembangkan kemampuan dan membentuk watak, serta peradaban bangsa yang bermartabat dalam rangka mencerdaskan kehidupan bangsa, bertujuan untuk berkembangnya potensi peserta didik agar menjadi manusia yang beriman dan bertakwa kepada Tuhan Yang Maha Esa, berakhlak mulia, sehat berilmu, cakap, kreatif, mandiri dan menjadi warga negara yang demokratis serta bertanggung jawab.

Kondisi di lapangan bertentangan dengan kenyataan, bahwa buku sebagai media belajar yang menjadi salah satu kunci ketertarikan mahasiswa dalam mempelajari dan memahami materi perkuliahan, namun keberadaannya belum sesuai dengan harapan yakni mempermudah mahasiswa dalam belajar.

Media adalah segala bentuk dan saluran yang dapat digunakan dalam suatu proses penyajian informasi" (Dwiyogo 2008:1). Dalam bahasa Arab media adalah perantara atau pengantar pesan dari pengirim ke penerima pesan, (Azhar Arsyad, 2011:3).

Berdasarkan beberapa pendapat di atas dapat disimpulkan bahwa media adalah segala bentuk benda atau komponen lain yang dapat digunakan untuk menyampaikan pesan dari pengirim ke penerima pesan sehingga dapat merangsang pikiran, perasaan, perhatian dan minat mahasiswa dalam proses belajar.

Penggunaan media diharapkan dapat mempermudah guru atau dosen dalam penyampaian materi pembelajaran atau materi kuliah dan juga membantu proses pembelajaran secara efektif dan efisien, serta mencapai sasaran penting dalam bidang pendidikan, khususnya pada pembelajaran. Sesuatu dapat dikatakan sebagai media pendidikan/pembelajaran apabila media tersebut digunakan untuk menyalurkan/menyampaikan pesan dengan tujuan-tujuan pendidikan dan pengajaran. "Media pembelajaran adalah segala sesuatu yang dapat digunakan untuk menyalurkan pesan dan merangsang terjadinya proses belajar pada si pembelajar siswa atau mahasiswa" (Aqib Zainal, 2014:50).

Menurut (Dwiyogo 2008:1) "Media pembelajaran adalah bahan/alat, maupun metode/teknik yang digunakan dalam kegiatan belajara-mengajar, dengan maksud agara proses interaksi komunikasi antara guru/dosen dengan anak didik/warga belajar dapat berlangsung 
secara tepatguna dan berdayaguna". Menurut (Syamsurijal, 2009:7) menyatakan bahwa "Media pembelajaran adalah bahan alat maupun metode/teknik yang digunakan dalam kegiatan belajar-mengajar dengan maksud agar proses interaksi komunikasi edukasi antara pengajar dan peserta didik dapat berlangsung secara tepat guna dan berdaya guna, baik melalui perangkat keras maupun dengan perangkat lunak". Sedangkan menurut (Hujair AH. Sanaky, 2013:4) "Media pembelajaran adalah sarana atau alat bantu pendidikan yang dapat digunakan sebagai perantara dalam proses pembelajaran untuk mempertinggi efektifitas dan efesiensi dalam mencapai tujuan pengajaran".

Batasan yang telah disampaikan oleh beberapa ahli mengenai media pembelajaran, maka dapat disimpulkan bahwa media pembelajaran merupakan segala bentuk alat komunikasi yang dapat digunakan sebagai penghubung dalam kegiatan pembelajaran, baik melalui perangkat keras, maupun lunak untuk meneruskan informasi (pesan) dari sumber (pemberi pesan) ke penerima pesan/informasi, dengan maksud merangsang pikiran, perasaan, minat dan perhatian siswa atau mahasiswa sehingga proses interaksi komunikasi edukasi antara guru atau dosen (atau pembuat media) dan siswa atau mahasiswa dapat berlangsung secara tepatguna dan berdayaguna. Terkait penelitian dan pengembangan ini, produk merupakan media pembelajaran yang digunakan untuk menyampaikan pesan, informasi atau bahan dalam kegiatan belajar dalam kaitannya dengan kegiatan belajar yang secara efektif dan efisien.

Buku merupakan salah satu media pembelajaran yang sangat di butuhkan dalam proses pembelajaran, seperti hanya buku ajar. Buku ajar adalah "buku yang secara cermat, sistematis di susun oleh ahli bidang studi tertentu atau profesi guru/dosen/widya iswara untuk mencapai tujuan pembelajaran, oleh karena itu, buku ajar dirancang oleh ahli tertentu dan dimaksudkan untuk menunjang tercapainya tujuan pembelajaran, maka jelaslah bahwa buku ajar memiliki sasaran pembaca yang sangat khusus yakni pelajar, lebih khusus lagi adalah pembelajar yang sedang dalam pengelolaan guru/dosen/widyaswara yang bersangkutan" (Dwiyogo, 2008:22).

Bahan ajar dalam hal ini buku teks yaitu buku tentang suatu bidang studi atau ilmu tertentu yang disusun untuk memudahkan para guru/dosen dan siswa/mahasiswa dalam upaya untuk mencapai tujuan pembelajaran, (Riyana, 2007:14). 
Berdasarkan beberapa pendapat di atas maka dapat ditarik suatu kesimpulan, buku ajar merupakan salah satu bentuk sumber belajar selain guru atau dosen, yang dirancang secara sistematis oleh ahli bidang studi tertentu atau profesi guru atau dosen, menurut kaidahkaidah perancangan dengan tujuan meningkatkan efektifitas dan meningkatkan ketertarikan pembelajar untuk terus belajar.

\section{METODE}

Dalam penelitian pengembangan ini, peneliti mengacu model pengembangan (research and development) Brog dan Gall (dalam Winarno, M.E 2011:76-77), yang telah dimodifikasi oleh peneliti yakni:

1. Need assessment. Melakukan penelitian yang merupakan analisis kebutuhan (need assessment), melalui penyebaran angket analisis kebutuhan pada 30 mahasiswa jurusan PJKR IKIP Budi Utomo Malang, sesuai dengan langkah pertama Borg dan Gall yang dikutip Winarno, research and information collecting.

2. Planning. Melakukan perencanaan pembuatan produk buku ajar tenis mejabagi mahasiswa jurusan PJKR IKIP Budi Utomo Malang sesuai dengan langkah kedua Borg dan Gall yang dikutip Winarno.

3. Pengembangan produk serta pengevaluasian terhadap para ahli yang sesuai dengan langkah ketiga Borg dan Gall yang dikutip Winarno. Develop preliminary form of product. Produk yang dikembangkan sesuai definisi buku. Buku dimulai dengan tulisan yang dibuat seseorang, yang berawal dari huruf, kemudian tersusun menjadi kata demi kata, baris demi baris, lalu paragraf demi paragraf, membentuk bab demi bab sampai akhirnya menjadi sebuh buku, (Leo, 2010:1).

4. Produk awal yang sudah terbentuk dijustifikasi oleh 1 orang ahli media pembelajaran dan 1 orang ahli pembelajaran tenis meja (materi isi).

5. Langkah selanjutnya, produk yang telah dijustifikasi oleh para ahli diuji cobakan di mahasiswa jurusan PJKR IKIP Budi Utomo Malang dengan melibatkan 10 subjek uji coba sesuai dengan langkah keempat Borg dan Gall yang dikutip Winarno. Preliminary field testing, conducted in from 1 to 3 schools, using 6 to 12 subjects.

6. Merevisi hasil uji coba dan memperbaiki atau menyempurnakan hasil uji coba sesuai dengan hasil dari uji coba tahap I (kelompok kecil) sesuai dengan langkah kelima Borg dan Gall yang dikutip 
Winarno. Main product revision, revision of product as suggested by the preliminary field-test results.

7. Uji coba produk akhir atau uji coba kelompok besar pada mahasiswa jurusan PJKR IKIP Budi Utomo Malang dengan melibatkan 32 subjek uji coba.

8. Penyempurnaan produk hasil uji coba lapangan berdasarkan hasil dari uji coba lapangan sesuai dengan langkah ketujuh Borg dan Gall operational product revision, revision of product as suggested by main field-test results.

Jenis data yang digunakan dalam pengembangan pembelajaran ini adalah data kualitatif dan kuantitatif. Data kualitatif diperoleh dari hasil wawancara dan hasil evaluasi para ahli yang berupa saran serta masukan. Sedangkan data kuantitatif diperoleh dari data angket analisis kebutuhan untuk mahasiswa, uji coba kelompok kecil, dan uji lapangan.

Teknik analisis data yang digunakan dalam penelitian pengembangan ini adalah teknik analisis kualitatifdan kuantitatif. Teknik analisis kualitatif bersifat induktif yaitu suatu analisis yang diperoleh berdasarkan hasil data. Sedangkan teknik analisis kuantitatif bersifat deskriptif berupa persentase.

\section{HASIL}

\section{Analisis Kebutuhan (Wawancara danAngket)} bahwa:

Hasil analisis kebutuhan terhadap buku ajar menunjukkan

1. Dari hasil variabel perasaan diperoleh $91 \%$

2. Dari hasil variabel peran diperoleh $92 \%$

3. Dari hasil variabel kegunaan diperoleh $75 \%$

4. Dari hasil variabel ketersediaan diperoleh $69,1 \%$

5. Dari hasil variabel alat evaluasi diperoleh $96 \%$ Secara umum $81,94 \%$ buku ajar dibutuhkan.

6. $63 \%$ menyatakan penyebab kesulitan belajar karena tidak tersediannya buku ajar, 97\% kesulitan belajar tenis meja karena kurangnya latihan, 30\% olahraga tenis meja tidak menarik, $70 \%$ kesulitan belajar tenis meja disebabkan materi di dalam buku yang tersedia dianggap kurang lengkap, dan 90\% terbatasnya buku yang ada.

7. $100 \%$ responden menghendaki materi teknik dasar pukulan forehand dan backhand, $100 \%$ teknik dasar memegang bet/raket, $90 \%$ jenis-jenis pukulan, $90 \%$ peraturan tenis meja, 
$90 \%$ model latihan dan pembelajaran tenis meja, $87 \%$ sejarah tenis meja, $80 \%$ cara melakukan pemanasan sebelum bermain tenis meja, dan $67 \%$ tipe permainan tenis meja.

Diketahui keinginan responden $100 \%$ menghendaki adanya materi teknik memegan bet, $100 \%$ materi pukulan forehand dan backhand, 90\% jenis-jenis pukulan, 90\% model latihan dan pembelajaran tenis meja dan $100 \%$ menghedaki adanya materi model dan variasi pembelajaran tenis meja.

\section{Pengembangan Produk} adalah:

Langkah-langkah pengembangan produk yang dilakukan

1. Mempelajari kurikulum di IKIP Budi Utomo Malang dan silabusnya.

2. Menyusun kisi-kisi.

3. Pengumpulan bahan/materi berupa buku referensi, buku pegangan pelatih dan rujukan dari Wibe site yang terkait serta pengalaman lapangan.

Hasil pengembangan produk berupa buku ajar di cetak pada kertas hvs 80 gram dngan ukuran 7,17x10,12 dengan tebal 140 halaman seting gambar dicetak berwarna.

Pengembangan produk dilakukandengan evaluasi dari ahli. Evaluasi ahliterhadap produk ini terdiri atas dua subjekyaitu ahli isi dan ahli media pembelajaran. Berdasarkan angket validasi ahli media pembelajaran dan ahli pembelajaran tenis meja diperolah hasil sebagai berikut:

a. Dari variabel isi dengan indikator $83,3 \%$.

b. Dari variabel strategi dengan indikator $80,3 \%$.

c. Dari variabel alat evaluasi dengan indikator $87,5 \%$.

d. Dari variabel hasil pembelajaran dengan indikator $85,7 \%$.

e. Dari variabel materi pembelajaran dengan indikator $80 \%$.

f. Dari variabel hasil gambar/ilustrasi dengan indikator $79,1 \%$.

Berdasarkan hasil validasi ke dua ahli yakni ahli media pembelajaran dan ahli pembelajaran tenis meja secara keseluruhan diperoleh hasil $82,21 \%$. 


\section{Uji Coba Lapangan}

Kegiatan uji lapangan dilakukan sebanyakdua kali yaitu. Uji coba kelompokkecil dilakukan oleh 10 subjek penelitian.Hasil analisis data uji coba kelompokkecil diperoleh 78,06\% dengan keterangan"baik" sehingga dapat dilanjutkan keuji coba kelompok besar. Ujicoba kelompok besar dilakukan oleh 32subjek penelitian. Hasil analisis data uji cobakelompok besar diperoleh 82,27\% denganketerangan "baik" sehingga Berdasarkan analisis porsentase yang ditetapkan bahawa jika pencapaian porsentase pada interval 70,1$90,0 \%$ berklasifikasi baik yang berarti buku ajar layak digunakan, dengan demikian hasil uji coba produk buku ajar tenis meja pada kelompok besar secara keseluruhan aspek yang dinilai telah mencapai $\mathbf{8 2 , 2 7} \%$ maka buku ajar yang telah disusun berklasifikasi baik dan bisa/layak digunakan sebagai bahan ajar.

\section{Hasil Revisi Produk}

Buku ajar tenis meja disusun berdasarkan analisis kebutuhan yang menyatakan $81,94 \%$ responden membutuhkan adanya buku ajar. Berdasarkan kurikulum (silabus dan deskripsi matakuliah tenis meja) sebagai acuan utama dan masukan/harapan/alasan kesulitan responden terhadap pembelajaran matakuliah tenis meja, disusun produk buku ajar tenis meja yang dalam prosesnya melalui tahapan: 1) validasi ahli media pembelajaran dan ahli pembelajaran matakuliah tenis meja, 2) uji coba kelompok kecil, dan Uji coba kelompok besar, didapatkan catatan-catatan evisi/review untuk penyempurnaan produk buku ajar tenis meja sebagai berikut:

\section{Review Validasi Ahli Pembelajaran dan Ahli Pembelajaran Matakuliah Tenis Meja}

a. Perlu modifikasi dengan memunculkan produk baru sebagi pembeda dengan buku referensi pada umumnya, sehingga nampak sebagai produk buku ajar. Atas review ini, telah dilakukan revisi dengan menambahkan 1 (satu) bab tentang model pembelajaran tenis meja (bab 6) sehingga memperjelas cara pembelajaran teknik dasar tenis meja.

b. Dalam hal pengetikan penulisan kutipan dari sumber rujukan harus mencantumkan nama, tahun dan halaman yang dikutip. Mencetak miring pada penggunaan kata asing. Memberi keterangan pada setiap gambar dan menulis sumber rujukan apabila mengutip gambar dari sumber tertentu. Menjunjung 
tinggi etika kejujuran akademik dengan mencantumkan sumber rujukan pada setiap bagian informasi, teori atau kalimat tertentu yang dikutip. Review tersebut telah dilakukan pada bagianbagian yang dimaksud sehingga setiap kutipan, sumber rujukan, mencentak miring setiap bahasa asing telah dilkakukan pada semua pembahasan yang ada pada produk buku ajar yang disusun.

c. Menyajikan deskripsi atau kompetensi bagian matakuliah yang ingin dicapai pada setiap bab diikuti rumusan tujuan pembelajaran dengan konsep audience, behavior, condition,degree (A, B, C, D), deskripsi yang menyatakan kompetensi dengan konsep A, B, C, D telah dilakukan pada setiap bab yang disertai tujuan pembelajaran yang ingin dicapai, sehingga setiap bab memiliki target pembahasan yang jelas.

d. Menyusun rangkuman pada setiap bab berdasarkan tujuan yang sudah disajikan. Revisi untuk menyusun rangkuman pada setiap bab telah dilakukan sesuai dengan tujuan pembelajaran yang ditetapkan.

e. Menyusun soal atau latihan yang berorientasi dengan tujuan yang sudah disajikan pada setiap bab, dilengkapai kunci jawaban. Revisi dengan menyusun kunci jawaban telah dilakukan pada setiap soal atau latihan pada setiap bab.

f. Menyajikan buku dalam format bolak-balik dengan kualitas mendekati sama dengan penerbit. Buku ajar yang awalnya dicetak pada satu muka setiap halaman, telah dicetak bolakbalik sebagaimana menyerupai buku yang diterbitkan penerbit.

g. Melengkapi bagian akhir buku dengan daftar riwayat hidup penulis disertai foto diri. Produk buku ajar tenis meja yang disusun telah dilengkapai dengan daftar riwayat hidup beserat foto diri penyusun.

\section{HASIL DAN PEMBAHASAN}

Berdasarkan penelitian awal (analisiskebutuhan berupa wawancara dan angket mahasiswa diperolehbahwa dibutuhkan pengembangan buku ajar matakuliah tenis mejayang dapat digunakan untuk mahasiswa IKIP Budi Utomo Malang. Setelah itu peneliti mengembangkanproduk tersebut. Pengembanganproduk di evaluasi oleh dua ahli. Dari keduaahli tersebut memperoleh hasil "baik" sehinggapengembangan buku ajar mata kuliah tenis meja dapat di ujicobakan. Uji coba lapangan diperoleh hasil "baik"sehingga 
pengembangan buku ajar tenis meja bagi mahasiswa IKIP Budi Utomo Kota Malang.

Berdasarkan pengembangan produkyang dikembangkan melalui uji ahli dan ujilapangan maka dapat diperoleh kesimpulanbahwa buku ajar layak digunakan, dengan demikian hasil uji coba produk buku ajar tenis meja pada kelompok besar secara keseluruhan aspek yang dinilai telah mencapai $82,27 \%$ maka buku ajar yang telah disusun berklasifikasi baik dan bisa/layak digunakan sebagai bahan ajar. Produk pengembanganyang dihasilkan mempunyai beberapa kelebihan.Spesifikasi produk yang telah dikembangkanyaitu memiliki beberapa jenis latihan pembelajaran antara lain yaitu Pembelajaran Pukulan Forehand, Pembelajaran Pukulan Backhand, Pembelajaran Pukulan Servis, Pembelajaran Pukulan Push, Pembelajaran Pukulan Lop, Pembelajaran Pukulan Block, Pembelajaran Pukulan Smash

Model pembelajaran tersebut mudah dan aman dilakukan untuk mahasiswa. Selain itu, terdapat langkah-langkah serta gambar yang menunjang sehingga semakin mudah dipahami dan menarik minat pembaca.

\section{KESIMPULAN DAN SARAN Kesimpulan}

Berdasarkan pada pengembangan yang telah dilakukan, bahwa produk yang telah dikembangkan bisa digunakan untuk dosen maupun mahasiswa berdasarkan hasil uji produk.

\section{Saran}

Berdasarkan kesimpulan di atas, maka peneliti memberikan beberapa saran yaitu:

1. Saran pemanfaatan yakni perlu dipertimbangkan situasi dan kondisi sarana dan prasarana yang ada, bagi dosen seharusnya memberikan materi secara bertahap

2. Saran pengembangan lebih lanjut yakni untuk subjek penelitian dilakukan pada subyek yang lebih luas lagi sebagai uji coba kelompok, dan dalam menyebarluaskan pengembangan produk, sebelum disebarluaskan sebaiknya produk ini dievaluasi kembali dan diuji keefektivitasnya agar produk lebih sempurna dan bermanfaat untuk masyarakat luas. 


\section{DAFTAR RUJUKAN}

Aqib Zainal, 2014. Menjadi Penulis Buku Profesional. Bandung: $C V$. Yrama Widya.

Arsyad Azhar, 2011. Media Pembelajaran, Jakarta: Rajagrafindo Persada

Brown, 1996. Tenis Tingkat Pemula, Jakarta: Raja Grafindo Persada

Dwiyogo Wasis D. 2008. Aplikasi Teknologi Pembelajaran. Malang:

Fakultas Ilmu Pendidikan Universitas Negeri Malang.

Larry Hodges, 2007. Tenis Meja Tingkat Pemula, Jakarta: PT. Rajagrafindo Persada

Lardner, 1996. Teknik Dasar Tenis, Strategi dan Taktik yang Akurat, Jakarta Depdikbud, Direktorat Jenderal Pendidikan Tinggi PPLPTK

Muhajir, 2008. Pendidikan Jasmani Olahraga dan Kesehatan untuk SMA Kelas XI, Bandung: Erlangga

Riyana cepy. 2007. Medi Pembelajaran. Jakarta: Direktorat Jenderal Pendidikan Agama Islam Kementrian RI.

Rud Midgley, 2000. Ensik Lopedia Olahraga, Semarang: Dahara Prize

Sanaky Hujair 2013 Media Pembelajaran Interaktif-Inovatif, Jakarta: Kaukaba Dipantara.

Sutrman, 2008. Terampil Berolahraga Tenis Meja, Solo: Era Intermedia.

Syamsurijal. 2009. Pengembangan Media Pembelajaran Berbasisi Multimedia. Jurnal MEDTEK, Volume 1, Nomor 1, (rijalkalang@yahoo.com, diakses 16 pebruari 2014).

Winarno M.E. 2011. Metodologi Penelitian Dalam Pendidikan Jasmani. Malang: Media Cakrawala Utama Press.

Widyarso, 2008. Melatih Tenis Remaja, Jakarta: PT. Mandar Utama Tiga Books Division

Undang-Undang Republik Indonesia Nomor 20 Tahun 2003 Tentang Sisdiknas dan Peraturan Pemerintah R.I Tahun 2010 Tentang Penyelengaraan Pendidikan Serta Wajib Belajar. Bandung: PT. Citra Umbara.

Ensiklopedia Nasional Indonesia, 2014. Jakarta: PT. Delta Pamungkas 